\title{
Do all transport modes impact on industrial employment? Empirical evidence from the Spanish regions
}

\author{
Xavier Fageda \\ Department of Economic Policy, Universitat de Barcelona, Spain, xfageda@ub.edu \\ Marta Gonzalez-Aregall* \\ Department of Economic Policy, Universitat de Barcelona, Spain, m.gonzalez@ub.edu
}

\begin{abstract}
This paper examines the direct, indirect and total impacts of all transport modes on industrial employment in Spain from 1995 to 2008. Through spatial econometric methods, this study finds that only ports are able to generate positive total effects, and that the increase in industrial employment that a region obtains from having more kilometers of motorways results in less industrial employment in other nearby regions. In contrast, airports and railways do not have a relevant impact on industrial employment. Overall, the level of employment in a country's manufacturing activities is related with those transport infrastructures that improve its international connectivity.
\end{abstract}

Keywords: transportation, spatial econometrics, motorways, ports, railways, airports.

JEL Codes: L91, O14, R4

*Corresponding author

Acknowledgements: This work was supported by the Spanish Ministry of Economy and Competitiveness under Grant (ECO2012-38004); and the Regional Government of Catalonia under Grant (SGR2014-325). 


\section{INTRODUCTION}

Transport infrastructure is crucial for the economic development of regions, since better infrastructure implies a greater outlay of public capital and, hence, the higher productivity of private factors, fewer transport costs for firms and greater accessibility to territories. However, as suggested by Redding and Turner (2014), the analysis of the economic impact of transport infrastructure on regions requires that the effects related to growth be distinguished from those related to the reorganization of economic activity, population or employment.

Numerous empirical studies have examined the impact of infrastructure on economic growth, most of them using production functions (Aschauer, 1989; Munell, 1990; GarciaMilà and McGuire, 1992; Holtz-Eakin, 1994) or cost functions ${ }^{1}$ (Nadiri and Mamuneas, 1994; Morrison and Schwartz, 1996) to analyze the impact of public capital on countries or regions.

While a vast literature has been built up on the link between public capital and output (and, to a lesser extent, costs), few studies examine the impact of different modes of transport infrastructure on employment, using country or regional level data and those studies that do this analysis generally focus on just one specific mode. In fact, most of these studies have analyzed the effect of highways on employment with mixed results (Clark and Murphy, 1996; Duranton and Turner, 2012; Jiwattanakulpaisarn et al., 2009; Jiwattanakulpaisarn et al., 2010), some have focused on seaport infrastructure and obtain evidence of positive effects for European and Italian regions (Bottasso et al., 2013; Ferrari et al., 2010, respectively), and another group of studies has reported positive effects of airport infrastructure (Albalate and Fageda, 2016; Brueckner, 2003; Bloningen and Cristea, 2015; Percoco, 2010).

This paper examines the determinants of industrial employment in Spanish regions using annual data for the period that goes from 1995 to 2008. Controlling for various regional attributes, it examines the direct, indirect and total impacts of various modes of transportation, including roads, railways, ports and airports. This study focuses specific attention on identifying whether the different transport modes have an effect in terms of the growth of industrial employment or in terms of its reorganization within regions.

The methodology employed is based on the use of spatial econometric techniques. Specifically, this study considers a spatial Durbin model (SDM), which measures the spatial

${ }^{1}$ Melo et al. (2013) provide a meta-analysis of the impact of transport infrastructure on economic activity. 
interaction of the dependent and explanatory variables (LeSage and Pace, 2009) so that it can examine the direct effects on the areas in which the infrastructure is located and the spillover effects on neighboring regions. To this point, the impact on employment of a better endowment of transport infrastructure in one region on its neighbors is not, a priori, clear. Indeed, improved infrastructure may give rise to a competition effect associated with the agglomeration of activities in the region with better infrastructure and a complementary effect associated with improved access to other regions or international markets.

This research focuses on the industrial sector given its relevance for regional economies. ${ }^{2}$ Cohen and Morrison Paul (2004) argue that the focus on a particular sector offers more plausible and more interpretable results than a macroeconomic approach, while Holtz-Eakin and Lovely (1996) show that manufacturing activity benefits more than other productive sectors from improved transport infrastructure.

The industrial sector is clearly very important for regional economies, given that a high proportion of exports and $R \& D$ expenditure are associated with manufacturing activities. Note also that industrial establishments can occupy a variety of locations, while service industries tend to be located in the central business districts of major urban areas. In this regard, rather than addressing transport infrastructure that only improves intra-urban mobility, this study focuses on infrastructures that influence intra- and inter-regional mobility.

We find that that the aggregate effect of transportation on industrial employment is only positive and statistically significant in the case of ports. Regions with more kilometers of roads are able to attract more industrial employment but this is at the expense of nearby regions. In contrast, regions that benefit from having a large port, along with the regions located nearest to these port regions, obtain more employment in manufacturing activities without harming the other regions. Finally, we do not find any significant impact for airports and railways.

This research contributes to evaluate how transport infrastructure influences industrial activity. Thus, policy makers can analyze and understand the relevance of their investment decisions of different transport modes and the effect on industrial activity.

\footnotetext{
2 Other studies that examine the role of transportation or public capital on the industrial sector include Hulten and Schwab (1991), Cohen and Morrison Paul (2003, 2004), Morrison and Schwartz (1996) and Moreno and López-Bazo (2007).
} 
The rest of the paper is organized as follows: Section 2 describes the data; Section 3 justifies the explanatory variables selected and explains the econometric techniques used; Section 4 presents the main findings. The last section discusses policy implications.

\section{DATA}

This section describes the data and variables used to estimate the determinants of industrial employment across the Spanish regions by building a balanced panel dataset for the period that goes from 1995 to 2008. While homogeneous data of industrial employment for more recent periods are not available, the analysis for this period has the advantage that is not conditioned by the severe worldwide economic crisis from 2008 onwards.

This analysis considers the 47 Spanish provinces that correspond to the NUTS-3 level in the European territorial unit classification ${ }^{3}$; however, it excludes the Island regions (Balearic and Canary) and the two territories located in the North of Africa (Ceuta and Melilla) as it is unable to assess the indirect impact of surface transportation in these regions.

The employment data are based on the sector classification provided by Spain's National Institute of Statistics, which disaggregates employment statistics as follows: 1) Agriculture, livestock and fisheries; 2) Energy; 3) Industry; 4) Construction; 5) Market services; and 6) Non-market services. In this regard, this analysis is focuses on the industry sector.

While the literature generally considers the impact of the value of the public capital stock (related to transport infrastructure) on the monetary gross domestic product, this paper focuses on the relationship between industrial employment and physical indicators of transport infrastructure. Specifically, this analysis uses the number of kilometers of highways and railways, and port and airport traffic measured in tones and in kilograms of goods, respectively.

\footnotetext{
3 Eurostat's NUTS classification (Nomenclature of Territorial Units for Statistics) is the European Commission's hierarchical statistics system for referencing the economic territory of the EU. A NUTS-2 area should have a population between 800,000 and 3,000,000 inhabitants, while that of a NUTS-3 area should range between 150,000 and 800,000 inhabitants. In practice, the statistical territorial units are defined in terms of the existing administrative units in the Member States and do not necessarily fulfill these population limits. In Spain, NUTS 2 are the Comunidades Autónomas (autonomous communities, or first-level political and administrative divisions) and NUTS 3 are the provinces.
} 
Investment in transport infrastructure has two effects (Vickerman, 1987): in the short run, the investment itself reactivates the construction sector while, in the long run, the investment has an external effect on the region's production costs by reducing accessibility costs. Here, the use of physical indicators, as opposed to monetary indicators, should help isolate this long-run effect. Indeed, the use of physical measures should capture the services provided by the infrastructure more appropriately, while the stock of capital is essentially an indicator of construction costs.

However, the use of physical measures also has limitations as we are assuming that each kilometer has the same effect on industrial employment. Ideally, the best variable to measure the improvements in transport connections would be an accessibility variable. Unfortunately, it is not possible to collect data for a measure of improvements in accessibility for the considered period (1995-2008).

All variables used in this analysis are in $\log$-linearized form in order to estimate the output elasticity of these variables. Table 1 reports the variables used in the empirical analysis, the sources of information drawn upon and their descriptive statistics. Note that the dependent variable is total employment in the industrial sector, while the explanatory variables include physical indicators of transport infrastructure, density of population and levels of education. As additional explanatory variables, this model also includes the spatial lag of the dependent variable and spatial lags of the rest of the explanatory variables (for more details on the econometric approach, see the next section).

Table 1. Descriptive statistics of the variables used in the empirical analysis

\begin{tabular}{|c|c|c|c|c|c|c|}
\hline Variable & Description & Source & Mean & $\begin{array}{c}\text { Std. } \\
\text { Dev. }\end{array}$ & $\begin{array}{c}\text { Min. } \\
\text { Value }\end{array}$ & $\begin{array}{c}\text { Max. } \\
\text { value }\end{array}$ \\
\hline $\begin{array}{c}\text { Log } \\
\text { (Industrial_Employment) } \\
\text { DEPENDENT } \\
\text { VARIABLE }\end{array}$ & $\begin{array}{c}\text { Total number of employes in the } \\
\text { industrial sector in the Spanish } \\
\text { provinces } \\
\text { (NUTS-3 level) }\end{array}$ & $\begin{array}{c}\text { National } \\
\text { Statistics } \\
\text { Institute (INE) }\end{array}$ & 3.56 & 0.98 & 1.76 & 6.44 \\
\hline Log (Motorways) & $\begin{array}{c}\text { Infrastructure endowment in } \\
\text { kilometers } \\
\text { (NUTS-2) }\end{array}$ & $\begin{array}{c}\text { European } \\
\text { Commission's } \\
\text { Eurostat } \\
\text { agency }\end{array}$ & 6.65 & 0.73 & 4.70 & 7.75 \\
\hline Log (Railways) & $\begin{array}{c}\text { European } \\
\text { Commission's } \\
\text { Eurostat } \\
\text { agency }\end{array}$ & 6.97 & 0.79 & 4.64 & 7.78 \\
\hline
\end{tabular}

\footnotetext{
${ }^{4}$ In Spain, NUTS- 2 are the autonomous communities, or first-level political and administrative divisions.
} 


\begin{tabular}{|c|c|c|c|c|c|c|}
\hline Log (Port) & $\begin{array}{c}\text { Total amount of traffic of each } \\
\text { Port Authority aggregated by } \\
\text { province (NUTS-3) and in tones } 5\end{array}$ & $\begin{array}{c}\text { Spanish } \\
\text { Ministry of } \\
\text { Transport }\end{array}$ & 0.33 & 0.52 & 0 & 2.15 \\
\hline Log (Airport) & $\begin{array}{c}\text { Spanish } \\
\text { total amount of freight in } \\
\text { kilograms moved in the airports of } \\
\text { each province (NUTS-3) } \\
\text { operator } \\
\text { (Aena) }\end{array}$ & 0.22 & 0.62 & 0 & 3.54 \\
\hline $\log$ (Population density) & $\begin{array}{c}\text { total amount of the population of } \\
\text { the region divided by the area of } \\
\text { this region } \\
\text { (NUTS-3 level) }\end{array}$ & $\begin{array}{c}\text { National } \\
\text { Statistics } \\
\text { Institute (INE) }\end{array}$ & 4.07 & 0.48 & 2.2 & 6.65 \\
\hline $\log$ (Education) & $\begin{array}{c}\text { the percentage of people with } \\
\text { secondary education studies } \\
\text { within the total working age } \\
\text { population } \\
\text { (NUTS-3 level) }\end{array}$ & $\begin{array}{c}\text { Foundation- } \\
\text { IVIE }\end{array}$ & 2.00 & 1.06 & 0.56 & 2.97 \\
\hline
\end{tabular}

Source: Own elaboration based on different sources of information.

Note here that our data have three important limitations that must be taken into account in the interpretation of results of the empirical analysis. First, the data for the motorway and railway endowment variables are only available at the NUTS-2 level (in Spain, that of the Autonomous Communities). Data for monetary values of transport infrastructures (investments, capital stock) are available at the NUTS-3 level. However, we consider more appropriate the use of physical indicators as our dependent variable is employment of the industrial sector. In any case, we have run regressions with the monetary indicators at the NUTS-3 level and the performance of the model is worse than with the regressions reported in the text.

Regarding the measures of infrastructure stocks, there is a mismatch across the variables as some of them indicate usage equilibrium (as in the case of ports and airports, where the relevance of infrastructure is measured with traffic) and some others indicate public capital provision (as in the case of roads and railways, as they are measured in kilometers). Unfortunately, we have not able to collect better data. Data about traffic of roads and railways is not available for Spanish regions, while it has been not been possible to get comparable physical indicators of ports and airports.

Furthermore, we only have available aggregated data at the regional level so that some important complementarities between different transport modes (for example, an airport or a port is more competitive if it is surrounded by a denser network of roads and/or railways) cannot be identified.

\footnotetext{
${ }^{5}$ The ports of Almeria (province of Almeria) and Motril (province of Granada) were managed by a joint port authority until 2002. To assign traffic to each province when they were managed by a joint port authority, it is needed to calculate the relative weight of traffic in each port when they were managed separately.
} 
While these data limitations may impose some bias in the estimation, we do not expect that they distort the sign and statistical significance of the main variables considered in the empirical analysis. However, they may have an effect on the magnitude of the coefficients.

Finally, this section gives a brief descriptive analysis of the regional distribution of the dependent variable and transport variables in Spain. An examination of the geographical distribution of employment in the manufacturing sector reveals a marked difference between coastal areas and the interior.

Figure 1 depicts the regional allocation of employment in manufacturing industry. ${ }^{6} \mathrm{Of}$ the twelve Spanish provinces presenting the highest manufacturing employment figures (accounting for more than half the country's total), nine are located on the coast and three in the interior. These twelve provinces can be grouped in three geographical areas: the Mediterranean coast (including Barcelona and Valencia), the Ebro Valley (including Bilbao and Zaragoza), and Madrid. On the other hand, with the exception of Madrid, the provinces with the lowest employment values are located in the interior.

\footnotetext{
${ }^{6}$ Stata software provides us with the map of the distribution of employment in the manufacturing industry by quantile measures grouped in four different intervals of values.
} 


\section{Figure 1. Distribution of manufacturing employment (NUTS-3)}

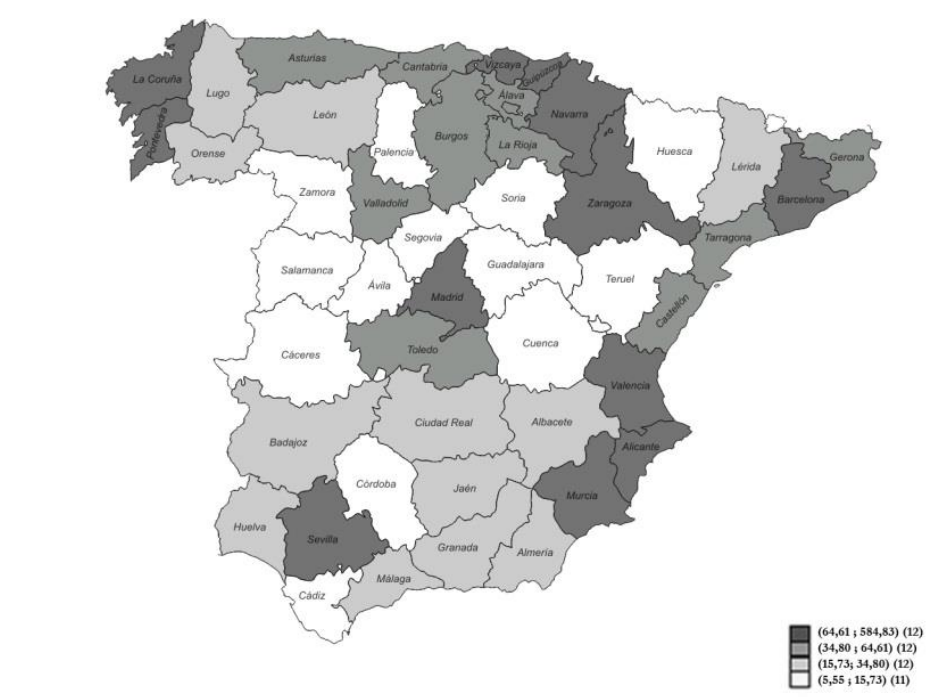

Source: Own elaboration based on the data on manufacturing employment

In terms of transport infrastructure, maritime and air transport services are more competitive on medium and long-haul routes, while road and railways may be better suited to short-haul routes. Figure 2 shows freight traffic distribution in Spain considering different modes of transportation at national and international levels. Data for the considered period are only available for 2007 and 2008 .

As can be seen, road transportation dominates freight traffic distribution at the national level; whereas maritime transportation handles the majority of cargo movements at the international level. In contrast, rail freight traffic and air cargo are not relevant in the overall freight traffic distribution. Thus, the international accessibility of the regions in Spain in terms of cargo seems to be based on ports. 


\section{Figure 2. Freight transportation by transport mode in Spain (thousand tones)}

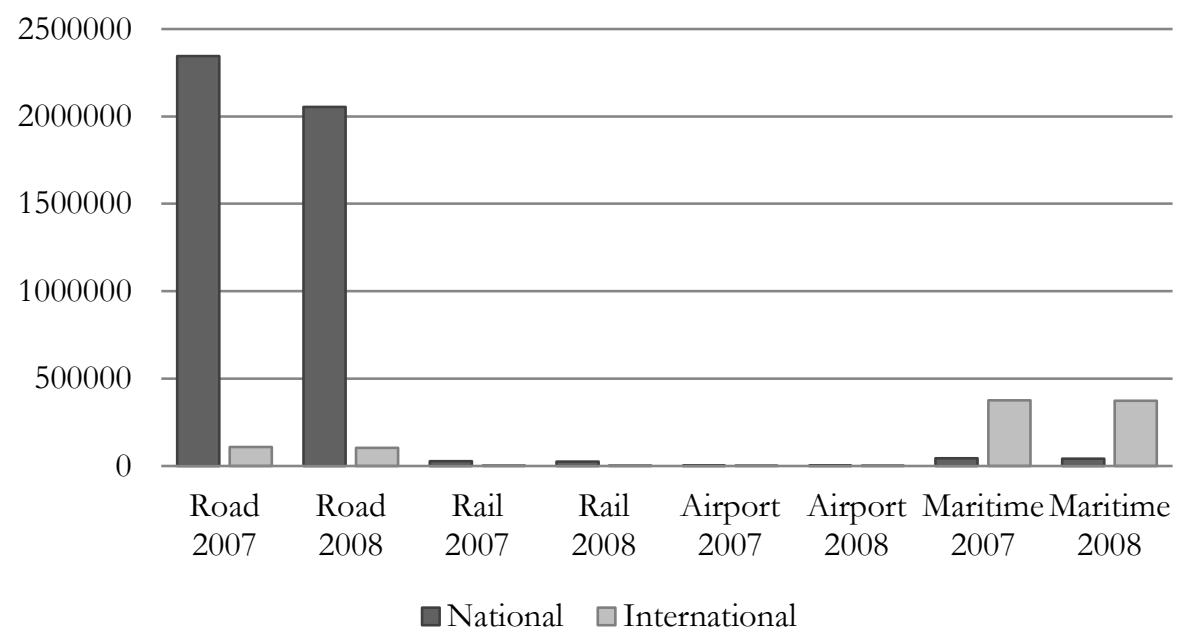

Source: Own elaboration based on Transportation and Logistics Observatory (OTLE-Ministry of Transportation).

An examination of the infrastructure variables reveals the geographical distribution of network modes (railways and motorways) to be quite similar. As one of Spain's transport objectives has been to improve connections between the political capital and the provincial capitals (Albalate et al., 2012), the region of Madrid has the highest density of motorways and railways in Spain - more than twice that of the regions with the next largest endowments, namely Catalonia, Valencia and the Basque Country. The density figures are quite similar in the case of railways. ${ }^{7}$ Note also that in the period under study, many of the motorways linking cities along the Mediterranean Coast and the Ebro Valley were tolled, while all motorways in the region of Madrid were toll-free (Bel and Fageda, 2005). In surface transportation modes, the mismatch between infrastructure demand and supply has become a significant characteristic of the policy aimed at connecting the political capital with all the provincial capitals (Albalate et al., 2015).

In contrast, the main ports are generally located on the Mediterranean coast. The Spanish port system comprises 28 port authorities managing 44 ports of general interest. The three largest, Algeciras, Barcelona and Valencia, are amongst Europe's top ten ports in volume of container traffic. Their privileged location in the Mediterranean Sea corridor allows them to channel the traffic from Asia to the South of Europe. Other ports with significant volumes of traffic are Bilbao, Tarragona and Cartagena, the last two also being located in the Mediterranean corridor.

\footnotetext{
${ }^{7}$ Since 2000, one of Spain's main transport objectives has been to provide a high-speed rail link between the political capital and all provincial capitals. The specific objective is that Madrid should be reached from all provincial capitals in a journey time of less than four hours.
} 
Finally, the Spanish airport system comprises 47 airports of general interest. The two largest, Madrid and Barcelona, concentrate about 75\% of the system's total air traffic of goods. Other airports with significant volumes of freight traffic are Zaragoza and Vitoria and, to a lesser extent, Valencia and Seville. Airport freight traffic is therefore mainly concentrated in the most populous cities and in the two specialized facilities in Zaragoza and Vitoria.

\section{THE EMPIRICAL STRATEGY}

\section{- VARIABLES}

This section presents an outline of the methodology and variables used for estimating the determinants of employment in the manufacturing sector. Given that the spatial spillovers between provinces may be especially relevant to this study, the regressions are conducted using spatial econometric techniques.

According to LeSage and Pace (2009), the spatial Durbin model (SDM) is the most suitable specification for modeling spatial effects. This model is characterized by including a spatially lagged dependent variable and spatially lagged explanatory variables (Elhorst, 2010a; 2010b; LeSage and Pace, 2009). Thus, in order to analyze the spatial interaction effects of the dependent variable and all the explanatory variables, the equation for estimating the determinants of employment for the corresponding province $i$ in year $t$ using a spatial Durbin regression is specified as follows:

$$
\begin{aligned}
\text { Ind_employment }_{\text {it }} & =\alpha_{0}+\alpha_{1} \mathrm{~W}^{*} \text { Ind_employment }_{\mathrm{it}}+\alpha_{2} \text { Motorways }_{\mathrm{it}} \\
& +\alpha_{3} \text { Railways }_{\mathrm{it}}+\alpha_{4} \text { Port }_{\mathrm{it}}+\alpha_{5} \text { Airport }_{\mathrm{it}} \\
& +\alpha_{6} \text { PopDens }_{\mathrm{it}}+\alpha_{7} \text { Education }_{\mathrm{it}}+\alpha_{8} \mathrm{~W}^{*} \text { Motorways }_{\mathrm{it}} \\
& +\alpha_{9} \mathrm{~W}^{*} \text { Railways }_{\mathrm{it}}+\alpha_{10} \mathrm{~W}^{*} \text { Port }_{\mathrm{it}}+\alpha_{11} \mathrm{~W}^{*} \text { Airport }_{\mathrm{it}} \\
& +\alpha_{12} \mathrm{~W}^{*} \text { PopDens }_{\mathrm{it}}+\alpha_{13} \mathrm{~W}^{*} \text { Education }_{\mathrm{it}}+\mu D_{t}^{\text {year }} \varepsilon_{\mathrm{i}}
\end{aligned}
$$

where, the dependent variable (Ind_employment) corresponds to the number of employees in the industrial sector in province $i$ at time $t$. As discussed above, this analysis includes as the main explanatory variables measures of the respective endowments of transport infrastructure (motorways, railways, port and airports) and two control variables: density of population and education. Furthermore, in this equation we include the spatial lag of the dependent variable and the spatial lag of the explanatory variables where $\mathrm{W}(\mathrm{N} \times \mathrm{N})$ is a 
spatial weight matrix that defines dependence across $\mathrm{N}$ regions. ${ }^{8}$ By introducing these additional spatial variables, the SDM takes into account the way in which the variation in the explanatory variable for a single region can affect the dependent variable in all other regions. Indeed, when interpreting the resulting coefficients it is important to consider that a change in a single observation associated with any given explanatory variable affects the region itself (a direct impact) and may affect all the other regions indirectly (an indirect impact).

Overall, we expect a positive sign for the coefficient associated with the non-spatial variables: in other words, all direct effects should be positive. Specifically, a better endowment of transport infrastructure is expected to lead to lower transportation costs so that local producers can buy cheaper inputs, specialize in those activities for which the region has a comparative advantage or find new markets and products. ${ }^{9}$

Within a given province, a better endowment of surface transport infrastructure (motorways and railways) may lead to a reduction in transportation costs for firms and increase accessibility to territories. Both factors may attract new manufacturing firms and promote the expansion of established firms. Note that this analysis assumes that when better surface transportation modes improve mobility within the region, this will lead to improved mobility between neighboring regions. Likewise, it assumes that an increase in provincial port and airport freight traffic will improve national and international accessibility so that both exports and imports become cheaper for local firms.

Employment in manufacturing activities should also be higher in provinces with a higher density of population given that the exploitation of scale economies is easier and transportation costs decrease. As the empirical analysis exploits differences between provinces, we not expect to find a centrifugal effect attributable to congestion, as such an effect would only be of relevance when analyzing the location of manufacturing firms within a given province. Finally, the availability of skilled workers may also have a positive effect on the employment level in the manufacturing sector in a given province.

Previous studies find evidence of a strong positive spatial autocorrelation of unemployment rates between adjacent areas using data for United Kingdom (Patacchini and Zenou, 2007) and Spain (Suárez et al., 2012) so that neighborhood influences are very

\footnotetext{
${ }^{8}$ According to Hughes (2011), when the number of time periods is higher than ten, it is reasonable to estimate a model with a spatially lagged dependent variable. In our case, the number of time periods is fourteen.

9 Interestingly, some theoretical models suggest that improvements to transport infrastructure lead to the opening up of markets and increase the degree of competition to which local producers are exposed (Ferrari et al., 2012). If local producers are not efficient, improvements to transport infrastructure may spur the import of cheaper goods so that local employment actually decreases.
} 
important in labor markets. Hence, we may expect a positive sign of the coefficient associated with the spatially lagged dependent variable.

The expected direction of the indirect effect of the transport infrastructure variables is a priori unclear. On the one hand, it may be positive as the connectivity provided by highways and railways extends beyond the region in which the infrastructure is located. However, it may be negative because the nearby region with better infrastructure attracts employees from other regions. Similarly, provinces that are close to others that are endowed with large ports and/or airports may take advantage of easier access to the goods produced in distant markets, while those provinces with large ports and/or airports may also attract employees from nearby provinces without large ports or airports.

Several studies have examined the spillovers between regions generated by transport infrastructures with inconclusive results. On the one hand, it can be expected that transport infrastructures lead to positive spillovers as they improve the connectivity of geographically linked regions (Cohen and Morrison Paul, 2003; 2004; Chen and Haynes, 2015; Tong et al. 2013; Yu et al.; 2013; Arbués et al, 2015; Bronzini and Piselli, 2009). On the other hand, negative spillovers are typically attributed to the migration of mobile production factors (Boarnet, 1998; Cohen and Monaco, 2007; Moreno and López-Bazo, 2007).

The indirect effect of the density population variable is not, a priori, clear either as transport costs should be lower due to the proximity to dense markets; however, the more densely populated region may attract production factors due to the higher returns associated with agglomeration economies. The indirect effect of the education variable is expected to be negative because more productive provinces, thanks to their greater endowment of skilled employees, may draw resources from other nearby provinces.

\section{- METHODOLOGY}

A central element in the estimation of a spatial model is the specification of the spatial weight matrix $(\mathrm{W})$. The $\mathrm{W}$ is a positive matrix $(\mathrm{NxN})$ that illustrates the dependence between units, where the elements $\left(w_{i j}\right)$ reflect the link between $i$ and $j$. Here, different specifications of the weight matrix can be applied. The most common approach is to apply a spatial weight matrix based on physical contiguity (i.e., when regions share borders) and a spatial weight matrix based on geographic distance between regions. Other spatial weight matrices are based on the similarity between regions' economic characteristics (for example, income levels) or on their trade relations. Anselin (1988) considers that the elements in the weight matrix should be non-stochastic and exogenous to the model. Thus, an advantage 
of specifying the matrix W based on location is that the elements are exogenous (Elhorst and Halleck-Vega, unpublished results).

This analysis estimates an SDM with four different specifications according to the spatial weight matrix used. In order to consider the closest neighbors but also more distant regions, the model is based on binary weight matrices with four different classifications: contiguity, a radius of $150 \mathrm{~km}$, a radius of $300 \mathrm{~km}$ and a radius of $450 \mathrm{~km}$. Thus, with these different distance thresholds, it can be possible to check the sensitiveness of the results for the spatial variables to the spatial weight matrix chosen.

To begin with, this analysis considers a binary contiguity matrix $\left(\mathrm{W}_{c}\right)$ with elements $\mathrm{w}_{\mathrm{ij}}=1$ when two units share a common border and $\mathrm{w}_{\mathrm{ij}}=0$ in all other cases. Second, the empirical model supposes three different binary weighted matrices with elements $\mathrm{w}_{\mathrm{ij}}=1$ for those provinces located within a distance of $150 \mathrm{~km}\left(\mathrm{~W}_{150}\right)$, a distance of $300 \mathrm{~km}\left(\mathrm{~W}_{300}\right)$ and a distance of $450 \mathrm{~km}\left(\mathrm{~W}_{450}\right)$ from the capital city of the province of reference and $\mathrm{w}_{\mathrm{ij}}=0$ for the other provinces. The first weight matrix assumes that spillovers only take place between regions within the considered threshold of geographic proximity, while the others assume that more distant regions also contribute to geographical spillovers.

In order to calculate the spatial interaction effects, we estimate equation (1) using the maximum likelihood method with a bias-correction procedure. Furthermore, we calculate the marginal effects to distinguish between direct, indirect and total effects.

To this point, it is relevant to test whether the SDM can be simplified to the spatial error model or to the spatial lag model. Hence, we consider the results from the Wald test and the likelihood ratio (LR) test. Results of these tests confirm that the SDM is appropriate for this analysis. Furthermore, we compare fixed and random spatial effects models in order to determine which of the two models is most suitable. According to Arbués et al. (2015), random effects should not be applied because the values of each spatial unit for the case of the Spanish provinces are not obtained arbitrarily. Consequently, the most suitable model is the SDM with spatial and time-period fixed effects (Elhorst, 2012a, 2012b). Note also that the literature generally does not provide any support for the random spatial effect estimation (Elhorst, 2012b). Here, an advantage of the fixed effects model is that it controls for any omitted variables that correlate with the variables of interest and which do not change over time. Thus, the fixed effects model may control for time-invariant omitted variables that simultaneously affect regional employment and the infrastructure variables. As a disadvantage, the fixed effect model only captures the within variation of the data. 
Finally, it is relevant to consider the potential bias derived from the simultaneous determination of the manufacturing employment and transport infrastructure variables. The endogeneity problem should not be a concern in the case of surface transportation as investment in these modes in Spain has prioritized passenger rather than freight transport and it has not been guided by demand criteria (Albalate et al., 2012, 2015). Moreover, the endogeneity problem might not exist as the effect of infrastructure investment is not instantaneous (Arbués et al., 2015). More generally, it would be reasonable to argue that the activity in the manufacturing sector is unlikely to drive policy decisions across regions (Cohen and Morrison Paul, 2003).

While the endogeneity bias of the surface transportation variables should not be a concern in the context of this study, the potential endogeneity of the lagged dependent variable and of the port and airport traffic variables needs to be taken more seriously. To deal with the endogeneity problem of the lagged dependent variable, the parameters of this model are estimated using the maximum likelihood method based on the conditional loglikelihood function (Anselin, 1988) and the bias-correction procedure proposed by Lee and Yu (2010). The literature includes several examples that adopt this procedure to correct this potential endogeneity bias (Tong et al., 2013; Yu et al., 2013; Arbués et al., 2015).

Furthermore, we check the potential endogeneity of the infrastructure variables. In this regard, we have estimated IV panel data models with time dimension instrumental variables. According to Arbués (2015) and Rodriguez-Pose and Peralta (2015), we consider as instruments the infrastructures variables lagged by one period and two periods. With these instruments, we can run an endogeneity test for a subset of regressors that may be endogenous. Under the null hypothesis that the specified endogenous regressors can actually be treated as exogenous, the test statistic is distributed as chi-squared with degrees of freedom equal to the number of regressors tested. Table 2 shows the results of the endogeneity test using different combinations of the two lags of the potential endogenous variables. Results of the test confirm that the variables may be considered as exogenous.

Table 2- Endogeneity tests

\begin{tabular}{|c|c|c|c|}
\hline & $\begin{array}{c}\text { One and two lags of } \\
\text { the endogenous } \\
\text { variables as } \\
\text { instruments }\end{array}$ & $\begin{array}{c}\text { One lag of the } \\
\text { endogenous } \\
\text { variables as } \\
\text { instruments }\end{array}$ & $\begin{array}{c}\text { Two lags of the } \\
\text { endogenous variables } \\
\text { as instruments }\end{array}$ \\
\hline Endogeneity Test & 2.045 & 2.5 & 3.90 \\
\hline p-value & 0.72 & 0.64 & 0.42 \\
\hline
\end{tabular}


Finally, as we mention above, the standard approach used in linear regression models to interpret the parameter estimates cannot be applied. Indeed, in spatial econometric models, the parameter estimates contain information from the interaction of units that complicate their interpretation (Elhorst, 2014).

Consequently, according to the theoretical description provided by LeSage and Pace (2009), a change in the explanatory variable for a single region can potentially affect the dependent variable in all other regions. Following these authors, the partial derivative of dependent variable $\left(\mathrm{Y}_{\mathrm{t}}\right)$ with respect to the $\mathrm{X}$ explanatory variables takes the following $\mathrm{n} \mathrm{x}$ n matrix form:

$$
\partial \mathrm{Y}_{\mathrm{i}} / \partial \mathrm{X}_{\mathrm{ir}}=\mathrm{S}_{\mathrm{r}}(\mathrm{W})_{\mathrm{ij}}
$$

This $\mathrm{n} \times \mathrm{n}$ matrix refers to the effect of a one-unit change of a particular explanatory variable in one province on a dependent variable of all the provinces. Thus, these authors suggest to consider not only the own-partial derivatives, i.e. the direct effect that corresponds to the sum of the average of the main diagonal elements of the $\mathrm{n} \times \mathrm{n}$ matrix, but also the cross-partial derivatives, namely, the indirect effects that correspond to the sum of the average of the off-diagonal elements of the $\mathrm{n} \times \mathrm{n}$ matrix. Likewise, the total effects are the result of the sum of direct and indirect effects.

In this regard, in order to interpret all the parameter estimates in this model correctly, this research assumes that a direct effect is the result of a change in an explanatory variable in province $i$ on the dependent variable of this province. Similarly, the indirect effect occurs when a change in an independent variable in province $i$ has an effect on the dependent variable in all the other provinces.

\section{RESULTS}

Table 3 shows the results of the regressions based on the estimation that employs four alternative spatial weight matrices of the bias-corrected fixed effect model, while Table 3 shows the computation of the direct, indirect and total effects obtained from these regressions. ${ }^{10}$ Their respective fourth columns show the results when using the binary weight matrices with contiguity, a distance of $150 \mathrm{~km}$, a distance of $300 \mathrm{~km}$ and a distance of $450 \mathrm{~km}$, respectively.

As can be seen in Table 3, in all specifications, the Wald test and the Likelihood Ratio (LR) test indicate that the hypothesis that the SDM could be simplified to the Spatial Lag

\footnotetext{
${ }^{10}$ Spatial fixed effects and spatial random effects are not shown, but are available on request.
} 
Model or to the Spatial Error Model must be rejected. Hence, the SDM is considered to be the model that provides the best description of the data (Elhorst, 2012).

Table 3- SDM with different weight matrices (bias-corrected fixed effects)

\begin{tabular}{|c|c|c|c|c|}
\hline & W contiguity & W_150 & W_300 & $W_{-} 450$ \\
\hline Motorways & $\begin{array}{c}0.045 \\
(1.116) \\
\end{array}$ & $\begin{array}{c}0.202^{* * *} \\
(4.215) \\
\end{array}$ & $\begin{array}{c}0.110^{* *} \\
(2.900)\end{array}$ & $\begin{array}{c}0.152^{* * *} \\
(3.477)\end{array}$ \\
\hline Railways & $\begin{array}{c}0.041 \\
(0.839)\end{array}$ & $\begin{array}{c}0.074 \\
(1.496) \\
\end{array}$ & $\begin{array}{c}0.078 \\
(1.601)\end{array}$ & $\begin{array}{c}0.065 \\
(1.346) \\
\end{array}$ \\
\hline Port & $\begin{array}{c}0.361 * * * \\
(6.475)\end{array}$ & $\begin{array}{c}0.286^{* * *} \\
(5.409)\end{array}$ & $\begin{array}{c}0.312^{* * *} \\
(5.799)\end{array}$ & $\begin{array}{c}0.325^{* * *} \\
(5.918) \\
\end{array}$ \\
\hline Airport & $\begin{array}{c}0.027 \\
(0.447)\end{array}$ & $\begin{array}{l}-0.022 \\
(-0.353) \\
\end{array}$ & $\begin{array}{c}0.006 \\
(0.101)\end{array}$ & $\begin{array}{c}-0.025 \\
(-0.403) \\
\end{array}$ \\
\hline Education & $\begin{array}{c}0.160 * * * \\
(3.521)\end{array}$ & $\begin{array}{c}0.161^{* * *} \\
(3.493)\end{array}$ & $\begin{array}{c}0.200^{* * *} \\
(4.436)\end{array}$ & $\begin{array}{c}0.174 * * * \\
(3.733)\end{array}$ \\
\hline Density population & $\begin{array}{c}0.365^{* *} \\
(2.470) \\
\end{array}$ & $\begin{array}{c}0.382^{* * *} \\
(2.705) \\
\end{array}$ & $\begin{array}{c}0.481 * * * \\
(3.422) \\
\end{array}$ & $\begin{array}{c}.424 * * * \\
(2.813) \\
\end{array}$ \\
\hline $\mathrm{W}^{*} \mathrm{Y}$ & $\begin{array}{c}-0.007 \\
(-0.121) \\
\end{array}$ & $\begin{array}{c}-0.217 * * * \\
(-5.583) \\
\end{array}$ & $\begin{array}{c}-0.116 \\
(-1.144) \\
\end{array}$ & $\begin{array}{c}-0.022 \\
(-0.195) \\
\end{array}$ \\
\hline $\mathrm{W} *$ Motorways & $\begin{array}{c}-0.158^{* *} \\
(-1.988)\end{array}$ & $\begin{array}{c}-0.204 * * * \\
(-3.826)\end{array}$ & $\begin{array}{l}-0.0005 \\
(-0.007)\end{array}$ & $\begin{array}{c}-0.273^{* *} \\
(-2.261)\end{array}$ \\
\hline W*Railways & $\begin{array}{c}-0.132 \\
(-1.136)\end{array}$ & $\begin{array}{c}-0.005 \\
(-0.067) \\
\end{array}$ & $\begin{array}{c}-0.079 \\
(-0.665)\end{array}$ & $\begin{array}{c}-0.039 \\
(-0.252) \\
\end{array}$ \\
\hline $\mathrm{W}^{*}$ Port & $\begin{array}{c}0.297 * * * \\
(2.621) \\
\end{array}$ & $\begin{array}{c}0.009 \\
(0.123) \\
\end{array}$ & $\begin{array}{l}0.375^{*} \\
(1.791) \\
\end{array}$ & $\begin{array}{l}0.467 * \\
(1.623)\end{array}$ \\
\hline$W^{*}$ Airport & $\begin{array}{c}-0.108 \\
(-0.862) \\
\end{array}$ & $\begin{array}{c}-0.153 \\
(-1.472) \\
\end{array}$ & $\begin{array}{c}-0.027 \\
(-0.121) \\
\end{array}$ & $\begin{array}{c}-0.836 * * \\
(-2.445) \\
\end{array}$ \\
\hline $\mathrm{W}^{*}$ Density population & $\begin{array}{c}0.328 \\
(1.172)\end{array}$ & $\begin{array}{c}0.029 \\
(0.161)\end{array}$ & $\begin{array}{l}-0.525^{*} \\
(-1.845)\end{array}$ & $\begin{array}{c}-0.518 \\
(-1.033)\end{array}$ \\
\hline $\mathrm{W}^{*}$ Education & $\begin{array}{c}-0.016 \\
(-1.507) \\
\end{array}$ & $\begin{array}{c}0.075 \\
(0.986) \\
\end{array}$ & $\begin{array}{c}-0.025 \\
(-0.191)\end{array}$ & $\begin{array}{c}-0.011 \\
(-0.049)\end{array}$ \\
\hline Time fixed effects & Yes & Yes & Yes & Yes \\
\hline Spatial fixed effects & Yes & Yes & Yes & Yes \\
\hline Wald Test Spatial Lag & $\begin{array}{c}21.665 \\
(p=0.0014)\end{array}$ & $\begin{array}{c}17.375 \\
(p=0.0080)\end{array}$ & $\begin{array}{c}9.538 \\
(p=0.1455)\end{array}$ & $\begin{array}{c}11.068 \\
(p=0.0863)\end{array}$ \\
\hline LR test spatial Lag & $\begin{array}{c}24.223 \\
(p=4.75 e-004)\end{array}$ & ( & $\begin{array}{c}10.944 \\
(p=0.0901)\end{array}$ & $\begin{array}{c}13.068 \\
(p=0.0420)\end{array}$ \\
\hline Wald Test Spatial Error & $\begin{array}{c}21.845 \\
(p=0.0013)\end{array}$ & $\begin{array}{c}20.613 \\
(p=0.0022)\end{array}$ & $\begin{array}{c}9.285 \\
(p=0.1585)\end{array}$ & $\begin{array}{c}11.002 \\
(p=0.0883)\end{array}$ \\
\hline LR test spatial Error & $\begin{array}{c}24.110 \\
(p=4.98 \mathrm{e}-004)\end{array}$ & - & $\begin{array}{c}10.031 \\
(p=0.1234)\end{array}$ & $\begin{array}{c}13.085 \\
(p=0.0417)\end{array}$ \\
\hline $\begin{array}{c}\text { Observations } \\
\text { R-squared } \\
\text { Corr-squared } \\
\text { Log-likelihood }\end{array}$ & $\begin{array}{c}658 \\
0.9894 \\
0.1258 \\
573.590 \\
\end{array}$ & $\begin{array}{c}658 \\
0.9892 \\
0.1353 \\
- \\
\end{array}$ & $\begin{array}{c}658 \\
0.9891 \\
0.1073 \\
569.122 \\
\end{array}$ & $\begin{array}{c}658 \\
0.9892 \\
0.1097 \\
568.512 \\
\end{array}$ \\
\hline
\end{tabular}

Note 1: Standard errors in brackets.

Note 2: Statistical significance at 1\%(***), 5\% (**), 10\% $\left(^{*}\right)$ 
The coefficients of the port traffic variable and the control variables of education and density of population are positive and statistically significant in all the spatial weight matrices. The coefficient of the motorways variable is positive and statistically significant except in the contiguity weight matrix. Likewise, the coefficient of railways is positive but not statistically significant in any of the regressions, and the coefficient of airports is not statistically significant in any of the regressions.

Thus, the results show an evidence of a positive direct effect of motorways and ports, and no effects of airports and railways, on industrial employment. This analysis shows that the level of employment in the manufacturing sector is higher in regions with larger ports and with a better endowment of motorways. In terms of magnitudes, a $1 \%$ increase in port traffic in a region increases the level of employment in manufacturing industry in the same region by $0.29-0.36 \%$. Additionally, the level of employment in the manufacturing sector is higher in regions with more kilometers of motorways. The elasticities for this variable are around $0.05-0.22 \%$.

The results of this analysis for ports are in line with Bottasso et al. (2013) and Ferrari et al. (2010) but they differ from those obtained by Arbués et al. (2015) Note here that the physical measures used to measure the endowment of ports may lead to an overestimated effect of ports over employment. Furthermore, the results for motorways are in line with those obtained by Duranton and Turner (2012). Likewise, Tong et al. (2013) reported positive effects of road expenditure on agricultural activities; while Yu et al. (2013) reported positive effects of surface transportation modes.

A possible explanation for the lack of impact of the airport and railway variables is that in Spain passengers have priority over goods in air and rail transportation policies. Furthermore, there is a high concentration of goods being moved by Madrid and Barcelona airports, so that industrial employment in these provinces may be better explained by other variables, including density of population, motorways (Madrid) or port traffic (Barcelona) variables. Furthermore, investment in transport infrastructure in Spain since the 1990s has focused on the high-speed rail network, which is not designed to be truly compatible with freight. Indeed, Spain's freight rail transport represents one of the lowest shares in Europe (Albalate et al., 2015).

As for the spatially lagged independent variables, the spillover effect of motorways is negative and statistically significant in all regressions except that in which the spatial weight matrix employs a $300-\mathrm{km}$ radius. The railway coefficient is not statistically significant in any 
of the regressions, while that of the airports variable is negative but only statistically significant in the regression for the spatial weight matrix that uses a $450-\mathrm{km}$ radius. Finally, the coefficient of the port variable is positive in all the regressions; however, it is not statistically significant in the regression in which the spatial weight matrix uses a $150-\mathrm{km}$ radius.

As for the control variables, the education variable is not statistically significant, while the results for the population density variable are inconclusive as the sign of the coefficient and the statistical significance vary according to the weight matrix used. In contrast to previous studies that use spatial models to examine the evolution of local and regional employment, the coefficient of the spatially lagged dependent variable is negative although not statistically significant (except in the regression that uses the spatial weight matrix with a distance of $150 \mathrm{~km}$ ). A possible explanation of differences in the results of our analysis in relation to previous studies is that we concentrate on the industrial sector while previous studies analyze all sectors as a whole.

Table 4- Direct, Indirect and Total spillover effects of SDM

(bias-corrected fixed effects)

\begin{tabular}{|c|c|c|c|c|}
\hline & W contiguity & W_150 & W_300 & W_450 \\
\hline \multicolumn{5}{|l|}{ Direct effects } \\
\hline Motorways & $\begin{array}{c}0.041 \\
(0.978)\end{array}$ & $\begin{array}{c}0.225^{* * *} \\
(4.271)\end{array}$ & $\begin{array}{c}0.112^{* * *} \\
(2.946)\end{array}$ & $\begin{array}{c}0.153 * * * \\
(3.524)\end{array}$ \\
\hline Railways & $\begin{array}{c}0.038 \\
(0.792)\end{array}$ & $\begin{array}{c}0.076 \\
(1.500)\end{array}$ & $\begin{array}{c}0.078 \\
(1.577)\end{array}$ & $\begin{array}{c}0.067 \\
(1.380)\end{array}$ \\
\hline Port & $\begin{array}{c}0.361^{* * *} \\
(6.592)\end{array}$ & $\begin{array}{c}0.292^{* * *} \\
(5.237)\end{array}$ & $\begin{array}{l}0.313^{* * *} \\
(5.791)\end{array}$ & $\begin{array}{c}0.323^{* * *} \\
(5.992)\end{array}$ \\
\hline Airport & $\begin{array}{c}0.032 \\
(0.517)\end{array}$ & $\begin{array}{c}-0.083 \\
(-0.124)\end{array}$ & $\begin{array}{c}0.009 \\
(0.150)\end{array}$ & $\begin{array}{c}-0.024 \\
(-0.384)\end{array}$ \\
\hline Density population & $\begin{array}{c}0.353^{* *} \\
(2.428)\end{array}$ & $\begin{array}{c}0.387^{* *} \\
(2.609)\end{array}$ & $\begin{array}{c}0.483^{* * *} \\
(3.494)\end{array}$ & $\begin{array}{c}0.426^{* * *} \\
(2.890)\end{array}$ \\
\hline Education & $\begin{array}{c}0.163^{* * *} * \\
(3.668)\end{array}$ & $\begin{array}{c}0.161 * * * \\
(3.383)\end{array}$ & $\begin{array}{c}0.201 * * * \\
(4.530)\end{array}$ & $\begin{array}{c}0.170^{* * *} \\
(3.615)\end{array}$ \\
\hline \multicolumn{5}{|l|}{ Indirect effects } \\
\hline Motorways & $\begin{array}{c}-0.159 * * \\
(-2.001)\end{array}$ & $\begin{array}{c}-0.225^{* * *} \\
(-4.025)\end{array}$ & $\begin{array}{c}-0.012 \\
(-0.193)\end{array}$ & $\begin{array}{c}-0.273 * * \\
(-2.189)\end{array}$ \\
\hline Railways & $\begin{array}{c}-0.133 \\
(-1.106)\end{array}$ & $\begin{array}{c}-0.018 \\
(-0.270)\end{array}$ & $\begin{array}{c}-0.081 \\
(-0.720)\end{array}$ & $\begin{array}{l}-0.040 \\
(-0.252)\end{array}$ \\
\hline Port & $\begin{array}{l}0.294 * * \\
(2.617)\end{array}$ & $\begin{array}{c}-0.050 \\
(-0.730)\end{array}$ & $\begin{array}{l}0.306^{*} \\
(1.655)\end{array}$ & $\begin{array}{c}0.433 \\
(1.525)\end{array}$ \\
\hline Airport & $\begin{array}{c}-0.114 \\
(-0.921)\end{array}$ & $\begin{array}{c}-0.141 \\
(-1.478)\end{array}$ & $\begin{array}{c}-0.031 \\
(-0.154)\end{array}$ & $\begin{array}{c}-0.819 * * \\
(-2.488)\end{array}$ \\
\hline Density population & $\begin{array}{c}0.339 \\
(1.173)\end{array}$ & $\begin{array}{c}-0.047 \\
(-0.267)\end{array}$ & $\begin{array}{l}-0.524^{*} \\
(-1.983)\end{array}$ & $\begin{array}{c}-0.519 \\
(-1.032)\end{array}$ \\
\hline
\end{tabular}




\begin{tabular}{|c|c|c|c|c|}
\hline \multirow{2}{*}{ Education } & -0.161 & 0.033 & -0.044 & -0.019 \\
& $(-1.568)$ & $(0.461)$ & $(-0.369)$ & $(-0.091)$ \\
\hline Total effects & \multicolumn{4}{|c|}{} \\
\hline \multirow{2}{*}{ Motorways } & -0.117 & -0.0004 & 0.100 & -0.120 \\
& $(-1.260)$ & $(-0.011)$ & $(1.457)$ & $(-1.066)$ \\
\hline \multirow{2}{*}{ Railways } & -0.094 & 0.057 & -0.003 & 0.027 \\
& $(-0.679)$ & $(0.909)$ & $(-0.022)$ & $(0.168)$ \\
\hline \multirow{2}{*}{ Port } & $0.656^{* * *}$ & $0.242^{* * *}$ & $0.619^{* * *}$ & $0.755^{* *}$ \\
& $(5.021)$ & $(3.339)$ & $(3.197)$ & $(2.501)$ \\
\hline \multirow{2}{*}{ Airport } & -0.082 & -0.149 & -0.021 & $-0.844^{* *}$ \\
& $(-0.589)$ & $(-1.525)$ & $(-0.101)$ & $(-2.438)$ \\
\hline \multirow{2}{*}{ Density population } & $0.692^{* *}$ & $0.338^{* *}$ & -0.041 & -0.093 \\
& $(2.563)$ & $(2.175)$ & $(-0.163)$ & $(-0.194)$ \\
\hline \multirow{2}{*}{ Education } & 0.002 & $0.194^{* *}$ & 0.156 & 0.151 \\
& $(0.017)$ & $(2.670)$ & $(1.270)$ & $(0.676)$ \\
\hline
\end{tabular}

Note 1: Standard errors in brackets.

Note 2: Statistical significance at $1 \%(* * *), 5 \%(* *), 10 \%\left(^{*}\right)$

In general, this paper find positive indirect effects associated with port traffic, although they are only clearly significant in the case of the contiguity matrix. Hence, the positive spillovers associated with large ports seem to concentrate in the immediate neighboring regions. In line with this result, Arbués et al. (2015) found that seaport investment in Spain can have positive effects, spilling over into neighboring regions. Similarly, Shan et al. (2014) reported a positive relation between per capita GDP and port traffic in China.

In the case of the indirect effects, the analysis obtains negative values of the motorway variable in almost all the weight matrices employed. As a result, an increase in a province's motorway infrastructure would yield negative effects on the employment of its neighbors with a magnitude that ranges from 16 to $27 \%$. Hence, a good endowment of motorways in one region negatively affects employment in the manufacturing sector in other nearby regions. Note here that this analysis may be limited by the fact that the dependent variable is provided at the NUTS-3 level (in Spain, that of the provinces), while the surface transportation variables are at the NUTS-2 level (in Spain, that of the regions). This may distort the magnitude of the indirect effect obtained for network modes; yet, we do not expect this data limitation to affect the direction and statistical significance of the spillover effects.

As for motorways, the results shows evidence that the negative effect associated with the migration of employees to more productive regions is stronger than the positive effect associated with the improved connectivity of less productive regions. This finding is in line with Holl (2004), who analyzes the impact of road transport infrastructure on the location 
of manufacturing establishments using micro-level data for Spain. The author finds that the benefits from road improvements are concentrated near the new infrastructure.

Note also that several studies of spatial spillovers focus specifically on road transport infrastructure. This may be because the literature usually examines the relationship between output and investments, and because the investment in roads accounts for a large share of the sector's total investment in transportation. In this regard, these results are in line with Boarnet (1998), Chandra and Thomson (2000) and Ozbay et al. (2007), who find clear evidence of negative spatial spillovers from investments in motorways, and with HoltzEakin and Schwartz (1995), who also reject the existence of positive spillovers in motorways.

To this point, Puga (2002) reviews the seminal papers about the regional impact of transport infrastructures within the new economic geography models framework. These models suggest a complex relationship between transport costs and regional disparities depending on the initial conditions of regions. In a context of models with a rich and a poor region, a reduction in transport costs only lead to a reduction in regional disparities when such reduction is substantial. In a context of models with similar regions (in a random geographical concentration process), a reduction in transport costs only lead to a reduction in regional disparities when the mobility of the labor force is low. In any case, these models suggest that the aggregate effect of transport infrastructures is ambiguous as they may benefit some regions at the expenses of others which are consistent with the results of our analysis for roads.

Furthermore, results of our analysis for roads are also in line of those obtained by studies that use data at a smaller spatial scale. In this regard, these studies examine the role of highways in the distribution of population between the central city and suburbs in United States (Baum-Snow, 2007), China (Baum-Snow et al., in press) and Spain (GarcíaLópez, 2012; García-López et al., 2015). They all found that highways lead to a reorganization of population within cities as an increase in the number of radial highways cause a reduction in the share of population in the central city.

Finally, it is not surprising that this study does not find strong indirect effects for the airport and railway variables. Indeed, such infrastructures do not even seem to have a large impact on their own regions, which may explain why the spillovers generated in other regions (either positive or negative) are modest. 
Overall, therefore, the results of this analysis suggest that the total effects are only positive and statistically significant for ports. The increase in industrial employment generated by a region with more kilometers of roads is associated with less employment for other regions. In contrast, regions that reap the benefits of having a large port and the regions located nearest to them generate more employment in manufacturing activities without harming employment levels in the other regions.

\section{CONCLUSIONS}

This study has analyzed the effects of transportation infrastructure on employment levels in manufacturing industry for 47 Spanish provinces between 1995 and 2008. It shows that some types of transport infrastructure significantly influence employment in the manufacturing sector. Motorway infrastructures and the level of port traffic have a positive and statistically significant direct impact, while railways and the amount of airport traffic have no clearly observable effects. Proximity to large markets (measured in terms of population density) and the availability of skilled labor also have marked direct effects.

This empirical analysis shows that there are significant negative spatial spillovers in the case of motorways. In contrast, it recognizes that a region with a large port is able to generate positive effects on neighboring regions.

In short, this paper provides evidence that the expansion of industrial activity in a country is mainly dependent on the infrastructure that enhances its international connectivity. The effects of this infrastructure on industrial employment seem to be related to growth. In contrast, the effects of the infrastructure that improve the connectivity of the regions within a country seem to be related to the reorganization of industrial employment in that country.

In Spain, ports are the mode of transport infrastructure that appears to have promoted this international connectivity. However, the movement of goods by air is concentrated in the two largest cities, while investment in rail has focused on high-speed rail lines that are not compatible with freight and serve only to improve connectivity within the country. While the movement of goods by road is sizeable both at the national and (to a lesser extent) international levels, this analysis suggests that motorways tend to reorganize a country's employment in the industrial sector more than they generate additional activity.

Hence, this study infers from the empirical analysis that the promotion of a country's industrial activity requires a focus on the infrastructure that supports its international 
connectivity, as is the case of ports. In Spain, the promotion of cargo at smaller airports might also be advisable given that the regions in which the main passenger airports are located are already attractive to industrial firms because of the size of their markets. Furthermore, investment in roads that cross national borders (such as those that constitute the international E-road network) and the development of international rail services dedicated to freight may help make a country more attractive to industrial firms.

Although this study has focused on Spanish regions, this analysis could be extended to other regions and countries in order to figure out the effect of improve infrastructure on the economic activity. 


\section{REFERENCES}

Albalate, D., Fageda, X. (2016) High-tech employment and transportation: Evidence from the European regions. Regional Studies 50, 1564-1578.

Albalate, D, Bel, G and Fageda, X. (2012) Beyond the efficiency-equity dilemma: Centralization as a determinant of government investment in infrastructure, Papers in Regional Science 91(3), 599-615.

Albalate, D., Bel, G; Fageda, X. (2015) When supply travels far beyond demand: Institutional and regulatory causes of oversupply in Spain's transport infrastructure, Transport Policy 41, 80-89

Arbués, P, Baños, J.F., Mayor, M (2015) The spatial productivity of transportation infrastructure, Tansportation Research Part A 75, 166-177

Baum-Snow, N. (2007) Did highways cause suburbanization? Quarterly Journal of Economics 122, 775-805.

Baum-Snow, N., Brandt, L.J., Henderson, V. and Turner, M.A (in press) Roads, railroads and decentralization of Chinese cities, Review of Economics and Statistics

Bel, G and Fageda, X. (2005) "Is a mixed funding model for the highway network sustainable over time?," in Ragazzi, G and W. Rothengatter (Eds) Procurement and Financing of Motorways in Europe. Elsevier, 195-211.

Anselin, L (1988) Spatial Econometrics, in Kluwer Academic Publishers (Eds), Amsterdam

Aschauer, D.A. (1989) Is Public Expenditure Productive?, Journal of Monetary Economics 23 (2), 177-200.

Blonigen, B.A., Cristea, A.D. (2015). Airports and urban growth, Evidence from a quasinatural policy experiment, Journal of Urban Economics 86, 128-126.

Boarnet, M.G. (1998) Spillovers and the locational effects of public infrastructure, Journal of Regional Science 38 (3), 381-400

Bottasso, A; Conti, M; Ferrari, C; Merk, O; Tei, A (2013) The impact of port throughput on local employment: Evidence from a panel of European regions, Transport Policy 27, 32-38.

Bronzini, R. and Piselli, P.(2009) Determinants of long-run regional productivity with geographical spillovers: The role of $\mathrm{R} \& \mathrm{D}$, human capital and public infrastructure, Regional Science and Urban Economics 39 (2), 187-199.

Brueckner, J.K (2003) Airline traffic and urban economic development, Urban Studies 40 (8), 1455-1469 
Chandra, A. and Thompson, E.(2000) Does public infrastructure affect economic activity? evidence from the rural interstate highway system, Regional Science and Urban Economics 30 (4), 457-490.

Chen, Z. and Haynes, K.E (2015) Public surface transportation and regional output: A spatial panel approach, Papers in Regional Science 94, 727-751.

Clark, D. E. and Murphy, C.A. (1996) Countywide employment and population growth: An analysis of the 1980s, Journal of Regional Science 36 (2), 235-256.

Cohen, J. and Monaco, K. (2007) Ports and Highways Infrastructure: an Analysis of Intraand Interstate Spillovers, International Regional Science Review 31 (3), 257-274.

Cohen, J.P. and Morrison Paul., C.J (2003) Airport infrastructure spillovers in a network system, Journal of Urban Economics 54 (3), 459-473.

Cohen, J.P. and Morrison Paul., C.J. (2004) Public infrastructure investment: Interstate spatial spillovers, and manufacturing costs, Review of Economics and Statistics 86 (2), 551560.

Duranton, G, and Turner, M.A. (2012) Urban growth and transportation, Review of Economic Studies 79(4), 1407-1440.

Ferrari, C, Percoco, M and Tedeschi, A. (2010) Ports and Local development: Evidence from Italy, International Journal of Transport Economics 37 (1), 9-30.

Ferrari, C, Merk, O, Bottasso, A, Conti, M and Tei, A. (2012) Ports and Regional Development: a European Perspective,Working Papers No. 17, OECD Regional Development.

García-López, M.A (2012) Urban spatial structure, suburbanization and transportation in Barcelona. Journal of Urban Economics 72, 176-190.

García-López, M.A., Holl, A. and Viladecans-Marsal, E. (2015) Suburbanization and highways: When the Romans, the Bourbons and the first cars still shape Spanish cities. Journal of Urban Economics 85, 52-66-

Elhorst, J.P, (2010a) Applied Spatial Econometrics: Raising the Bar, Spatial Economic Analysis 5 (1), 9-28

Elhorst, J.P, (2010b) Spatial Panel Data Models, In Getis A. in Fischer M.M. (eds) Handbook of Applied Spatial Analysis, Springer.

Elhorst, J.P, (2012a). Dynamic spatial panels: Models, methods and inferences, Journal of Geographical Systems 14 (1), 5-28

Elhorst, J.P. (2012b) Matlab Software for Spatial Panels, International Regional Science Review, doi: 10.1177/0160017612452429. 
Elhorst, J.P. (2014) Spatial Econometrics: From Cross-Sectional Data to Spatial Panels, Springer Briefs in Regional Science, DOI: 10.1007/978-3-642-40340-8_2

Elhorst,P and Halleck-Vega, S. On spatial econometrics models, spillover effects, and W, European Regional Science Association Conference Papers (unpublished results)

García-Milà, T and McGuire, T.J. (1992) The contribution of publicly provided inputs to states'economies, Regional Science and Urban Economics 22 (2), 229-241

Holl, A. (2004) Manufacturing location and impacts of road transport infrastructure: empirical evidence from Spain, Regional Science and Urban Economics 34 (3), 341- 363

Holtz-Eakin, D. (1994) Public Sector Capital and the Productivity Puzzle, Review of Economics and Statistics 76 (1), 12-21

Holtz-Eakin, D and Lovely, M.E. (1996) Scale economies, returns to variety, and the productivity of public infrastructure, Regional Science and Urban Economics 26, 105-123.

Holtz-Eakin, D. and Schwartz, A.E. (1995) Spatial productivity spillovers from public infrastructure: Evidence from state highways, International Tax and Public Finance 2(3), 459-468.

Hughes, G. (2011) Implementing procedures for spatial panel econometrics, in Stata Users Group meeting 2011

Hulten, C. R. and Schwab, R.M.(1991) Public capital formation and the growth of regional manufacturing industries, National Tax Journal 44(1), 121-134.

Jiwattanakulpaisarn,P, Noland,R.B, Graham,D.J. and Polak, J.W. (2009) Highway infrastructure investment and country employment growth: A dynamic panel regression analysis, Journal of Regional Science 49 (2), 263-286.

Jiwattanakulpaisarn,P, Nolan, R.B., Graham, D.J. (2010) Causal linkages between highways and sector-level employment, Transport Research Part A 44, 265-280.

Lee, L.F. and Yu, J. (2010) Estimation of spatial autoregressive panel data models with fixed effects, Journal of Econometrics 152(2), 165-185.

LeSage,J and Pace, R.K. (2009) Introduction to Spatial Econometrics, CRC Press, Taylor and Francis Group (Eds).

Melo, P.C., Graham,D.J and Brage-Ardao,R. (2013) The productivity of transport infrastructure investment: A meta-analysis of empirical evidence, Regional Science and Urban Economics 43 (5), 695-706.

Moreno, R and López-Bazo, E (2007) Returns to Local and Transport Infrastructure under Regional Spillovers, International Regional Science Review 30(1), 47-71. 
Morrison, C.J. and Schwartz, A.E. (1996) State infrastructure and productive performance, American Economic Review 86 (5), 1095-1111.

Munnell, A.H. (1990) How does public infrastructure affect regional economic performance?, New England Economic Review, Federal Reserve Bank of Boston. September/October, 11-32.

Nadiri, M.I. and Mamuneas, T.P. (1994) The effects of public infrastructure and R\&D capital on the coststructure and performance of U.S. manufacturing industries, The Review of Economics and Statistics 76 (1), 22-37.

Ozbay, K, Ozmen-Ertekin, D and Berechman, J (2007) Contribution of transportation investments to county output, Transport Policy 14 (4), 317-329.

Patacchini E. and Zenou Y (2007) Spatial dependence in local unemployment rates. Journal of Economic Geography 7, 169-191.

Puga, D. (2002) European regional policies in light of recent location theories, Journal of Economic geography 2, 373-406.

Percoco, M. (2010) Airport Activity and Local Development: Evidence from Italy, Urban Studies 47(11), 2427-2443.

Redding, S.J., Turner, M.A. (2014), Transportation costs and the spatial organization of economic activity, NBER Working paper, No. 20235, 1-59.

Rodríguez-Pose, A., Peralta, E.V (2015), Innovation and Regional Growth in Mexico: 2000-2010 Growth and Change 46, 172-195

Suárez P, Mayor M. and Cueto B (2012) The accessibility to employment offices in the Spanish labour market, Papers in Regional Science 91, 823-848.

Tong, T., Yu, T-H.E; Cho, S-H; Jensen, K. (2013) Evaluating the spatial spillover effects of transportation infrastructure on agricultural output across the United States, Journal of Transport Geograpby 30, 47-55.

Vickerman, R.W. (1987) The Channel Tunnel and regional development: a critique of an infrastructure-led growth project, Project Appraisal 2 (1), 31-40.

Yu, N., de Jong, M, Strom, S, Mi, J. (2013) Spatial spillover effects of transport infrastructure: evidence from Chinese regions, Journal of Transport Geography 28, 56-66. 